\title{
Economic Growth in the Eurasian Transition Economies: The Roles of Institutional and Structural Factors
}

\author{
Prof. Dr. Melike Bildirici (Yıldız Technical University, Turkey) \\ Assoc. Prof. Dr. Özgür Ömer Ersin (Beykent University, Turkey)
}

\begin{abstract}
The study aims to evaluate economic growth process and the problems faced by the selected transition economies in Eurasia during the transition period and especially after their independence. The countries analyzed are Azerbaijan, Kazakhstan, Kyrgyzstan, Tajikistan, Turkmenistan and Uzbekistan. The economic growth performances are evaluated with selected institutional and structural factors; namely, with political stability, democratization and corruption with panel regression analyses. Due to the availability of the data and to obtain a balanced panel of the analyzed countries, the sample is restricted to the 1987-2011 period. The empirical findings suggest that the role of democratization has been significant on growth for the period of transition and after the independence. Unexpectedly, the findings point at positive impacts of corruption on economic growth which suggest that high levels of corruption have significant effects on economic growth due to the enlargement of the informal economy and which translates itself on GDP growth rates. Empirical results also suggest that the success or failure in economic development in this regard is related to, in addition to measures taken in terms of economic reforms, the cooperation of the societies with these reforms, the level political stability, corruption, socialdemocratization of communist parties and failure or success in claiming the conducted reforms by the transition economies.
\end{abstract}

\section{Introduction}

If the countries which completed their transitionary process between the years of 1989-1991 are compared, the transition countries in Europe are more successful in terms of development. Furthermore, Poland, Czech Republic and Hungary reached the PPP adjusted GNI per capita levels that they had in 1989 by the year 1998. On the other hand, the PPP adjusted per capita income of Russia in the late 1990's is almost 50\% of the GNI per capita (PPP) that Russia had in year 1989. While examining the reasons behind the slowdown of growth in the transition countries, a fraction of the literature focuses on political decision-making, excessive spending, cumbersomeness and the combination of political decision-making with excessive spending and cumbersomeness and then increasing costs and expenditure and getting away from economical effectiveness.

In the study, an investigation of the development process followed after the independence by Azerbaijan, Kazakhstan, Kyrgyzstan, Tajikistan, Turkmenistan and Uzbekistan will be provided on the basis of socioeconomic, structural and political stability factors. The study also aims to analyze the relative success of the transition countries in Europe and the relative failure of former USSR countries. Accordingly, the institutional, economic and social factors are evaluated. These factors include democratization, political instability and corruption, extroversion, institutional and organizational factors.

\section{Investigation of Economic Growth, Institutional, Structural and Socioeconomic Indicators}

In the second part of the study, the concepts of institutional, structural and socioeconomic factors will be evaluated vis-à-vis the economic growth rates. In part 3, the institutional, socioeconomic and political factors will be analyzed within the economics literature framework. The econometric methods are given in part 4 . The analyses are conducted in the third section. Concluding remarks are given in the last section. The variables to be used in the study are the GDP per capita, the GDP per capita growth rates and possible impacts of institutional and political variables evaluated within the selected indices. Institutional and political variables evaluated in the study are the path followed by corruption, the political stability and democratization. These factors constitute the main focus of the study which aims at linking these factors to the economic performances.

\subsection{An Overlook of the Economic Growth in Selected Transition Countries}

A commonality that is faced while evaluating the pattern followed by the GDP per capita and GDP levels in the post-socialist countries is that sudden GDP decreases occurring following the transition. While a loss in terms of production that is reflected in the GDP series is expected phenomenon for countries experiencing transition, a striking feature of this fact is the length of the period of the low or negative GDP growth rates experienced by the evaluated transition countries. The average GDP per capita levels in 1990's, 2000's and in 2008- before the Global Economic Recession- is given in Figure 1. Since the year 2009 corresponded to the global down-turn, the post2008 period is not included to isolate the special effect of the transition. 


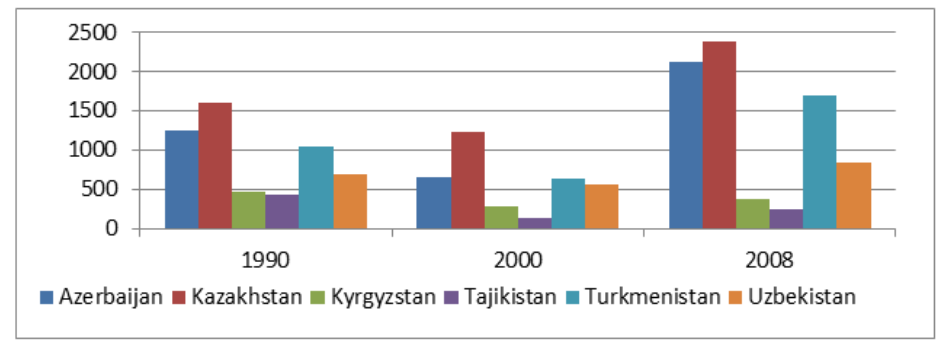

Figure 1. GDP per Capita in Selected Eurasian Economies Source: Worldbank, WDI

As observed in Figure 1, a similar pattern exists for GDP growth rates evaluated for the selected former USSR member countries. Though the WDI data is available starting from 1960's, considering the independence in early 1990's we focus on the growth performances of the transition countries for the 1990-2008 period. In 1990's, high GDP per capita levels are deserved special attention for Azerbaijan, Kazakhstan and Turkmenistan followed by Uzbekistan. Another striking feature is that the production level of these former USSR member countries in 1996, in terms of GDP per capita, is only $59 \%$ of the level they had when they were a member of USSR in 1987 . Further, in addition to the levels of production, the distribution of income and its evaluation throughout the years deserve attention as it hints possibly important social fractionalization or duality in terms of the income shares. The Gini coefficients calculated for 24 transition economies between 1986-2006, during the transition for the selected countries, are given in Figure 2.

Though the Gini coefficients represent the income distribution in these economies, they also show the income imbalances within the countries. The Gini coefficients between 1986-1990 represent substantial deterioration compared to the Gini coefficients in the post 1992 period. As there is a noticeable improvement between 20002002 compared to 1996-1998, if an overlook is to be presented, the mean Gini levels follow an increasing trend during the overall period. As a result, the factors that could result in such deterioration have a strong effect on the creation of the unfair distribution even though the GDP levels in the late 2000's are comparatively larger than those achieved during the early periods of transition. There are many macroeconomic factors that could lead to such results including the increases in the inflation rates and unemployment increases and other factors such as the privatization, dissolutions, adaptation or lack of adaptation of technologic advancements and the expected result of market economy that prioritizes productivity over equal pay. Among many factors, the study aims at focusing three of the most important factors to evaluate their effects on economic growth: democratization, political (in)stability and corruption.

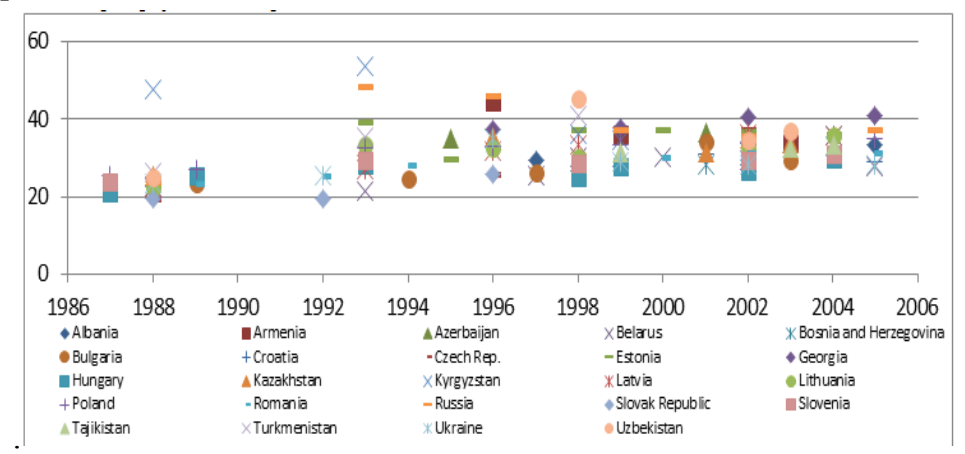

Figure 2. Gini Coefficients in the Transition Economies, 1986-2006. Source: Worldbank, WDI

\subsection{Democratization}

Democratization, political instability and corruption will be under the focus in evaluating the socioeconomic factors. Democratization is the most emphasized variable in socioeconomic factors; whereas, corruption and political instability have significant impacts on achieving economic development.

While analyzing the democratization in transition economies, one of the questions needed to be answered is "how could we define the relationship between democracy and economic growth or dictatorship and economic development?". There are many examples for both cases. We can easily say that democracy causes high speed growth if the view point is from the countries in Europe. Furthermore, Korea, Taiwan, Japan and India are the countries that showed significant successes in economic growth following their democratization policies; growth and high speed development followed by their democratic regime characteristics. Another important example on this subject is Indonesia. After the end of the dictatorship, the improvement in economic conditions deserve special attention. On the contrary, Malaysia does not have a liberal democracy although she has even better economic conditions. The studies focusing on the effects of regimes and economic growth fail to display a consensus on this relationship especially on the way of causality between these variables. We defined some of the crucial studies on these subjects below. 
Alesina and Drazen (1991), Roland (2000) and Fidrmuc (2003) pointed out that there were negative effects of democracy on economic growth whereas the main motivation on this negative effect is based on the election process and its consequences on the economy. Accordingly, the elections push the government to avoid having radical economic reforms that target to overcome loss of efficiency in the economy. In a similar fashion, Cheung (1998) attracts attention to the elections and also point to the importance of the time period of transition to democracy. Another study that discusses the positive and negative aspects of democracy is Tavares and Wacziarg (2001) study. In their analysis, Tavares and Wacziarg (2001) discuss not only the positive effects such as those that lower income inequality and augment the accumulation process of human capital but also the negative effects like lower accumulation of physical capital and greater involvement of government in the process towards democracy. Thus Tavares and Wacziarg (2001) state that the net effect was noted to be negative if the positive and negative aspects of democracy and their effects are to be evaluated in light of success in achieving economic growth.

The studies looking from the positive effect side of democracy on economic growth can be exampled as North (1990, 1993), Olson $(1993,2000)$. The main idea of these studies is that democracy ensures and guaranties better property rights. Another study that imposes the positive effects of democracy on growth is Rodrik (2000) which highlights the importance of local knowledge. Accordingly, the importance of low economic uncertainty causes high institutional outcomes and finally better response to adverse shocks.

These studies point that the debate on the subject are collected under two pillars. Krueger and Ciolko (1998) introduced an important approach by attracting attention to initial conditions versus policy choices on output decline for transition economies. In their study, they ascertain the endogenity hypothesis of the liberalization and they didn't reject it. Heybey and Murrell (1999) investigated the effects of the speed of liberalization on economic growth with an approach benefiting from simultaneous equations and found that both accumulated liberalization and the speed of liberalization had positive impacts on performance of growth. Another study analyzing the initial conditions and the growth performance in liberalization is Berg, Borensztein, Sahay and Zettelmeyer (1999) which aims to investigate the $U$ shaped per capita output over time - a common phenomenon experienced by all transition economies. They studied output level/output growth as dependent variable and utilized non-policy explanatory variables such as initial conditions and country dummies, and policy variables such as macroeconomic variables important for policies and structural reforms. They also find that the initial output decline in former Soviet Union is a result of slower structural reforms and they advise radical approaches to reforms. Havrylyshyn, Izvorski, Rooden (1998) analyzed the determinants of growth for 25 transition economies in the period 1990-1997. They found evidence for macroeconomic stabilization, structural reforms and low government expenditure on sustainable growth. Wolff (1999) suggested the J-curve effect on output growth of liberalization and shows that after a three year period, the increase in liberalization has positive effects on output and negative effects on inflation. Also Fidrmuc (2003) considered the trade-off between democracy and growth. One of the main results is economic liberalization has positive effect on growth; whereas, another important finding is the result that democracy facilitates liberalization and improves growth performance.

\subsection{Political Instability}

According to United Nations (2003), another factor that deserves to be investigated under the socio-economic factors is political instability. Political instability is investigated with its relationship to economic growth in many studies. Factors that evolve with political instability simultaneously with a parallel manner are hyperinflation, high rates of unemployment, high government expenditures and inefficiency in the structure of tax policies that results in budget deficits which lead to failure in transition of economic structure, inequality in distribution of income and sharp declines in happiness index and these factors cause also to a circular causation as the reasons and results behind underdevelopment. However, these macroeconomic variables are left out of the focus while the analysis in this paper aims at directing the analysis to investigating the political stability on growth in this section and in the empirical section.

In accordance with the political instability, the literature suggests interrelations with the structure of population, existence of minorities, the homogeneity or heterogeneity of the population, the existence of religious opposition, the parliamentary structure, polarization in the parliament and political massacres (Eren and Bildirici, 2000). In this respect, minorities, religious opposition wars, civil wars and terror attacks are evaluated among the factors that affect economic growth negatively. Ethnic heterogeneity is a very important factor that is a cause of political instability. All republics are, in varying degrees, multi-ethnic and republics have ethnic linkages to each other: Kazakhstan, Kyrgyzstan, Uzbekistan and Turkmenistan are all Turkish-speaking nations. One exception is Tajikistan, which differs by its Persian ethnic and cultural roots. The people of Tajikistan are predominantly Persian rather than Turkish origin. Ethnicity in Kyrgyzstan and ethnic minorities in the region are: Kyrgyz $52.4 \%$ Russian $18.0 \%$ Uzbek $12.9 \%$ Others $16.8 \%$ In Azerbaijan, it is Azerbaijan 82 \%, Russian 6\% and other \%12 (CIA, 2001). The figures in Uzbekistan are: Uzbek $71 \%$ and Russian $11 \%$ of population. Turkmens constitute $72 \%$ of Turkmenistan population (Eren and Bildirici, 2000).

One point that cannot be overlooked is the fact that the ethnic disputes and regional differences deserve significant attention by the economies evaluated. Starting from early 1990's ethnicity problems gained relevance and increasing problems. Political disputes such that those observed in Tajikistan were caused by on-going tensions 
regarding the Non-Central Asian minorities (Atkins, 1999). On the other hand, though the percentage of Russian were amounted to nearly 8 percent of the population, small fractions of communities such as Jews, Ukrainians Armenians, were considered collectively as the Russian-speakers, have shown their dissatisfaction before the era during which the political instability in light of the political tensions experienced gained significant attention. Russian is widely spoken in Uzbekistan, Kyrgyzstan, Tajikistan and in Kazakhstan (Eren and Bildirici, 2000).

In post-USSR countries, the shape of relationships between former USSR members have significant impacts on the development process. Cornell (2000) shows that, following the large proportion of the Russian-speaking populations; especially as is the case in Kyrgyzstan and Kazakhstan, the continued existence of these economies in its present shape could be put into question. Should these countries decide to embark on a more nationalistic, anti-Russian path is an important decision in the development process. Kyrgyzstan is a small country that shares this problem; moreover, it is vulnerable to its neighbors, China and Uzbekistan. Most members of these nationalities either supported the anti-reformists or emigrated. The emigration turned into a mass exodus by 1992 with the outbreak of civil war. Atkins (1999) shows shat another problem in Tajikistan and Uzbekistan is regarding "the problem of definition". Bukhara and Samarkand, cities that Tajiks consider as their most important cities in history, were assigned to Uzbekistan. Leaders of the new Uzbekistan tried to uzbekify the Tajik minority. "The problem of definition" of nationalization remain as significant points between Tajiks and Uzbeks to the present. During the height of the civil war, most Uzbeks in Tajikistan sided with the anti-reformist coalition and some took an active part in the fighting (Atkins, 1999).

Furthermore, the above mentioned problems in these countries co-exist with the ongoing problem regarding Afghanistan. Cornell and Sultan (2000) notes that a quarter of Afghanistan's population consists of mostly Tajiks, Uzbeks and Turkmens. In addition, Xinjiang, autonomous region in the Republic of China also has a large amount of Kazakh, Kyrgyz and Uzbek population. Though these ethnic links had considerable impact on the security of the concerned states, especially in an age of increased global ethnic awareness, the ethnic milieu of Afghanistan is affected increasingly by the cross-border ethnic linkages. These linkages are at times further strengthened by geopolitical and economic interests of stakeholders and actors in the region (Eren and Bildirici, 2000).

During the analyzed period, Azerbaijan went through certain problems in regards to its minorities: starting from 1989, the Nagorno-Karabakh autonomous region asked its autonomy in which Armenian nationalist played a crucial role in supporting the Nagorno-Karabakh region (Cornell and Sultan, 2000). Following the independence, the ongoing tension between the Armenians and Azeries led to a war during which around one-fifth of Azerbaijani territory became ruled by the Armenian authorities in October 1993 (Cornell, 2001).

In 1996, China, Russia, Kazakhstan, Kyrgyzstan, and Tajikistan inaugurated a diplomatic discourse regarding their mutual west Asian borders. On 26 April 1996, the Presidents of the five border countries signed an agreement in Shanghai on which fourteen agreements on border issues has been met in addition to the agreements in terms of economic and security issues of the mutual borders. The package is called the Shanghai Accord which established an important development in establishing a framework for border normalization. The Tajik military units controlled the Tajikistan border with Afghanistan. Further, the Afghanistan-Tajikistan border is considered as a path through which terrorist activities and illegal goods including drugs had found a route to destinations in Eurasia which was intertwined by the war between Azerbaijan and Armenia over the Nagorno-Karabakh discussed above. Thus the 1993-1996 period is considered as Azerbaijan's hard road to stability (Eren and Bildirici, 2000). After the Azerbaijani armed forces have suffered severe military setbacks in the fall of 1993, Armenian forces occupied the whole area between Karabakh and the Iranian border. In May 1994, as a military stalemate developed between Azerbaijan and Armenia, a cease-fire was signed. In 1995, a coup attempt took place, which was organized by a leader of the interior ministry forces, was deterred (Cornell, 2001). Nichol and Kim (2001) noted that this event that took place between Armenia and Azerbaijan resulted in complete displacement of ethnic Armenians from Azerbaijan and the opposite from Armenia. Another war that took place in Chechnia further increased the problems between Azerbaijan and Armenia in terms of the ongoing problems related to the Nagorno-Karabakh region. These particular set of events accelerated the ongoing instability to another level in the Caucasus region as the year 2003 was reached. One important result is the fact that the wars that had been happening in the region, following the cooperation between Armenia and Azerbaijan and between Georgia and Abkhazia, and following the Tajik civil war, another important event that extended the conflicts in the Eurasia had become the civil war in Afghanistan. Further, in late 2010's, the accelerated cultural conflicts in the region following the wars had also been affected from Russia's policies in Chechnya. Another event is the separatist movement in Xinjiang-Uigur Autonomous Republic of China that also contributed to the increased tensions in the region.

Especially Azerbaijan is very vulnerable and it has suffered several coups or attempted coups. A constitutional referendum in 1995 granted Azerbaijani President Heydar Aliyev sweeping powers. He has arrested many of his opponents. The 1995 legislative and 1998 presidential elections were marred by irregularities, according to international observers. The 1998 presidential election was very important. At first, the regime issued an electoral law that was rejected by both the OSCE and the opposition, which decided to boycott the elections. In response to the OSCE's criticism and after a dialogue with the opposition, the Aliev regime reformed the electoral law and abolished press censorship. These changes won the OSCE's approval (Cornell, 2001). In late June 2000, the 
Parliamentary Assembly of the Council of Europe (PACE) approved Azerbaijan's membership, conditioned on its compliance with commitments, including holding a free and fair legislative election. Although international observers also judged January 2001 legislative run-off elections as seriously flawed (Nichol and Kim, 2001). In elections in republics, it presented a crucial opportunity to change this state of affairs. But they produced another rubber-stamp parliament, through electoral fraud and opposition boycott (Eren and Bildirici, 2000).

The anti-government uprising in Hujand, Tajikistan, in November 1998 showed that the conflicts of the Tajikistan war had not been resolved by the Tajikistan peace accord. Uzbekistan was bombed by terrorist in Tashkent in February 1999. In this situation, in Kyrgyzstan, Security issues, reemerged with the onset of the Tajikistan war reemerged in summer 1999 with a hostage crisis. In August 2000 a new hostage crisis in Kyrgyzstan refocused attention on the country's vulnerability. In September, a military force had penetrated into Uzbekistan within 100 kilometers from the capital. Uzbekistan is the target of terrorist organizations, especially the IMU and has announced that its goal is to overthrow the Uzbekistan government. In Uzbekistan, legitimate political disagreement and political extremism, that is, political instability was increasing (Gleason, 2001).

In Uzbekistan during the first decade of independence, politics has been far from pluralistic or competitive. The political process is carefully monitored and controlled. Restrictions on the electoral registration process make it possible for the government to exercise a determining influence on the pre-selection of candidates. In theory, the judiciary is independent, but in practice, the capacity of the judiciary, being an independent branch of government is limited. The Constitution describes the legislature as the highest organ of power, in the country has a unitary. In reality, the branches are not coequal or balanced; the executive branch is dominant in virtually all matters (Gleason, 2001).

All these problems severely affected the region's political and economic development. On the other hand, the politically motivated violence, coups or attempted coups, and ordinary crime heightened the sense of insecurity in the republics. Parliaments and constitutional courts have been disbanded, elections are rigged and civil rights are systematically suppressed (Eren and Bildirici 2000). These had many important effects on instability.

All problems analyzed in the paper created increased political instability. In the empirical section, the study aims at focusing on the effects of political instability on economic growth in the selected countries.

\subsection{Corruption}

Corruption is defined as follows; "a purposeful intention not to stay away from advantageous activities of a person for himself or for an akin" (Tanzi, 1998). Johnson et. al. (1998), in their study analyzing certain Latin American, OECD and transition countries, identified significant relationships between corruption and the underground economic activities.

In the countries analyzed, a common characteristic is the fact that, the informal economy feeds on the following factors; namely, high interest rates on the government debt, the failure in the structure of tax policies, avoidance of taxes and the practice of tax evasion at high rates. Among the rising economies, the countries that have increasing volume of informal economy, are countries that have high political instability and those possessing democracy regime. In these countries, corruption and informal economy grows with an accelerating rate and also is nurtured with political instability. Even though the average economic growth rates are low in the countries that also have corruption and political instability, the rate of growth of the informal economy reaches high levels. As the informal economy in these countries in developed with increasing rates, the country shows periodically a low performance.

In 1999 in Kyrgyz Republic, the informal economy is estimated as $47.9 \%$ with the highest rate among the transition economies, whereas the rate reached $26.8 \%$ in Kazakhstan in the year 2000. Georgia's shadow economy was the largest, $64 \%$ of the GDP and Russia's was $44 \%$ of GDP (OECD, 2004). Among the transition countries that are located in central and eastern Europe in the same period, Bulgaria experienced a rate of $11.1 \%$ of their GDP in 2000 and Slovakia's and Czech Republic's were the smallest, at 7.3\% for the former and $5.6 \%$ for the latter.

Accordingly, the countries that possess corruption and informal economy at very low levels experience the stages of growth partially without problems and also are the countries that accomplish the transition process.

\section{Data and Econometric Methodology}

\subsection{Data}

The study aims to analyze Kazakhstan, Kyrgyzstan, Uzbekistan, Turkmenistan, Tajikistan and Azerbaijan. The data utilized in the study is gathered from the Gapminder Database, World Bank and IMF. The sample covers the 1987-2011 period and consists of yearly time series data for 6 countries. The variables are the corruption index, the political instability index and the democratization index. GDP data is collected from the World Bank, WDI database and represents the GNI in constant dollars. The data on democracy in collected from the Freedom House database. Political instability is taken from the Governance Indicators Database of the World Bank. All variables 
are log linearized with natural logarithms. After taking first differences, the first differenced variables represent their growth rates.

\subsection{Unit Root and Stationarity Tests with Structural Breaks}

The dataset is evaluated with Fisher Chi-square tests (Choi, 2001), Levin et. al. (2003) LLC unit root test and Carrion-i-Silvestre et al. (2005) stationarity tests that allow one or more structural breaks. The LLC panel unit root test is a panel unit root test that allows for fixed effects and unit specific time trends in addition to common time trends. The test may be evaluated as a pooled DF or ADF, potentially with differing lag lengths across the units of the panel and they use ADF tests to test for unit roots. Further, in the LLC test, the unit-specific fixed effects are an important source of heterogeneity. To save space, the structural break test results are not tabulated in the paper. However, the estimated structural break dates will be reported and evaluated in the econometric results below for the analyzed countries. The structural break test results are available upon request from the authors.

\section{Econometric Results}

\subsection{Unit Root and Stationarity Test Results}

At the first step, variables are evaluated with selected 1st generation panel unit root tests; namely, LLC, IPS, Fisher and Hadri tests. At the 2nd step, the stationarity of the variables are further investigated with the CBL stationarity tests. As noted in section 4, the selection of CBL test is based on the fact that it allows testing the stationarity by allowing multiple structural breaks both in the mean and in the slope. Further, the test is differentiated in the sense that it allows both for different number of structural breaks at unspecified dates and also by allowing for different structural break numbers and dates, the test procedure allows heterogeneity of panels investigated. At the $3 \mathrm{rd}$ step, panel regression analysis is conducted. The selected $1^{\text {st }}$ generation panel unit root tests are given in Table 1. To save space, the CBL stationary test that allow for heterogeneity in terms of multiple structural breaks are not reported. The results are available from the authors upon request. However, the calculated structural break dates will be reported within the texts below.

\begin{tabular}{|l|l|l|l|l|l|}
\hline Variables & LLC* & IPS & Fisher** & Hadri (homo)*** & Hadri (hetero) $* * *$ \\
\hline$\Delta g d p$ & -8.23 & -6.92321 & 70.37 & 8.0123 & 7.872149 \\
\hline$\Delta$ democi & -4.36 & -6.93430 & 36.68 & 7.7432 & 7.198170 \\
\hline$\Delta$ corrupi & -6.09 & -7.5349 & 41.90 & 9.6428 & 8.36507 \\
\hline Apoli & -7.14 & -9.6423 & 70.196 & 10.157 & 9.186 \\
\hline
\end{tabular}

Table 1. First Generation Unit Root Test Results

Notes. *LLC, IPS denote Levin, Lin \& Chu and Im, Pesaran and Shin panel unit root tests. ** ADF - Fisher Chi-square test. The test results are reported for the first differences to save space and $\Delta$ denotes first differences. *** Homoscedastic and heteroscedasticity-robust versions of Hadri test is reported.

The null hypothesis of LLC, IPS and Fisher tests are unit root; whereas, the null hypothesis in the Hadri test is stationarity of the variable. The results supported the hypothesis of a unit root in all variables across countries and therefore, the results for the first differenced series are reported. Accordingly, the series are accepted to be integrated I(1) of order one process and therefore, first differenced series are accepted to be taken into consideration for the panel regression analysis. If the tests are evaluated, it is concluded that the null hypotheses of stationarity are rejected for all of the series in levels. Accordingly, the null of stationary cannot be rejected at $5 \%$ significance level for all variables once the first differences of the series should be utilized in the panel regressions. This result is also confirmed with CBL tests. To include the effects of the structural breaks, dummy variables will be added in the regression analysis. It was noted in Section 1 that the countries evaluated went through some very sharp declines in in their GDP levels. As expected, the structural break dates calculated with the CBL tests coincide with the high downturns in terms of negative growth rates achieved by these countries. Azerbaijan experienced a negative growth rate of $-24.3 \%$ in 1993 and a single break is calculated for the year 1993 in Azerbaijan. The structural break dates calculated for Kazakhstan are 1992 and 1995 and the growth rate recorded as $-11 \%$ for 1991 and $-11.3 \%$ for 1994 , thus the calculated structural break dates denote two structural breaks following the years reported. Kyrgyzstan had sharp declines such as $-14.9 \%$ in $1992,-15.4 \%$ in 1994 and $-20 \%$ in 1995 and the structural break dates are calculated as the years 1991 and 1996. The GDP growth rates of Turkmenistan show highly negative values in years 1993, 1994 and 1997 with $-12.5 \%,-19.4 \%$ and $-12.6 \%$; whereas the structural break dates were calculated as 1996 and 1999. Considering the double V-shaped GDP path followed by Turkmenistan, the results were expected. The same analysis holds for Uzbekistan. The results suggested one break in the year 1994 and negative growth rates were recorded following the year $1992(-13.3 \%)$ in the country. Accordingly, sharp declines in terms of GDP growth rates are common for the evaluated transition countries following their independence after the dissolution of USSR.

Further, the break dates are calculated as 1999 and 2003 for Azerbaijan, 1995 and 1999 for Kazakhstan, 1991, 1997 and 2007 for Kyrgyzstan, 1994 and 2007 for Tajikistan, 1999 for Turkmenistan and 1993 for Uzbekistan. 


\subsection{Panel Regression Results}

The points asserted in analyses in terms of the transition economies are various and deserve special investigation. It is important to note that, in the literature, certain amount of studies use indices individually as proxies by leaving other indices out of the analyses. Following the discussion given in section 2, the following four panel regression models are estimated for 1989-2011 period,

Model 1: $\Delta g d p_{i t}=\beta_{0}+\beta_{1} \Delta$ corrupi $_{i t}+\beta_{2} D U_{i t}+u_{i t}$

Model 2: $\Delta g d p_{i t}=\beta_{0}+\beta_{1} \Delta$ democi $_{i t}+\beta_{2} D U_{i t}+u_{i t}$

Model 3: $\Delta g d p_{i t}=\beta_{0}+\beta_{1} \Delta$ poli $_{i t}+\beta_{2} D U_{i t}+u_{i t}$

Model 4: $\Delta g d p_{i t}=\beta_{0}+\beta_{4} \Delta$ corrupi $_{i t}+\beta_{5} \Delta$ democi $_{i t}+\beta_{6} D U_{i t}+u_{i t}$

Further, the following model is estimated to evaluate political instability and its effects on economic growth,

Model 5: $\Delta g d p_{i t}=\beta_{0}+\beta_{1} \Delta$ corrupi $_{i t}+\beta_{2} \Delta$ democi $_{i t}+\beta_{3} \Delta$ poli $_{i t}+\beta_{4} D U_{i t}+u_{i t}$

Where $g d p_{i t}$ represents the gross domestic product, corrupiit is the corruption index, demociit is the democratization index, poliit is the political stability index of country $i$ at year $t$. DUit is the dummy variable that equal 1 for the dated structural breaks for country i at year t. Since all variables analyzed are given in their first differences following the unit root tests, they represent their growth rates, respectively. Since all variables are in logarithms and in first differences, they are the growth rates denoted with a $\Delta$. As a typical, the economic growth

rate is denoted with $\Delta$ gdpit. Thus, $u_{i t}$ is assumed as following i.i.d. $N\left(0, \sigma^{2}\right)$ white noise process. The results for the estimated panel regressions are given in Table 2.

\begin{tabular}{|c|c|c|c|c|c|}
\hline \multirow[t]{2}{*}{ Dependent Variable: $\Delta$ gdp } & \multicolumn{5}{|l|}{ MODELS: } \\
\hline & $(1)$ & $(2)$ & $(3)$ & (4) & $(5)$ \\
\hline $\mathrm{c}$ & $\begin{array}{l}-10.03 * * * \\
(-3.12)\end{array}$ & $\begin{array}{l}2.085 \\
(1.15)\end{array}$ & $\begin{array}{l}2.98 * * * \\
(2.81)\end{array}$ & $\begin{array}{l}-3.44 * * * \\
(-4.30)\end{array}$ & $\begin{array}{l}1.089 * * * \\
(2.23)\end{array}$ \\
\hline$\Delta$ corrupi & $\begin{array}{l}1.21 * * * \\
(2.77)\end{array}$ & - & - & $\begin{array}{l}5.65 * * \\
(2.41)\end{array}$ & $\begin{array}{l}1.76^{* * *} \\
(2.83)\end{array}$ \\
\hline$\Delta$ democi & - & $\begin{array}{l}0.987^{*} \\
(1.95)\end{array}$ & - & $\begin{array}{l}3.80 * * \\
(2.23)\end{array}$ & $\begin{array}{l}0.56^{* * *} \\
(2.77)\end{array}$ \\
\hline$\Delta$ poli & - & - & $\begin{array}{l}0.62 * * \\
(2.53) \\
\end{array}$ & - & $\begin{array}{l}-0.28 * * \\
(-2.56) \\
\end{array}$ \\
\hline DU & $\begin{array}{l}0.116^{* *} \\
(2.475)\end{array}$ & $\begin{array}{l}1.52^{*} \\
(1.88)\end{array}$ & $\begin{array}{l}1.543 * * * \\
(3.723)\end{array}$ & $\begin{array}{l}1.112 * * \\
(2.281)\end{array}$ & $\begin{array}{l}0.88 * * * \\
(3.37)\end{array}$ \\
\hline $\mathrm{R}^{2}$ & 0.761754 & 0.7841 & 0.81 & 0.416758 & 0.7673 \\
\hline Log likelihood & -456.895 & -488.51 & -477.0163 & -416.2833 & -458.47 \\
\hline Cross-section F & $\begin{array}{l}6.720914 \\
\text { Prob:(0.000) }\end{array}$ & $\begin{array}{l}7.0145 \\
\text { Prob: } \\
(0.000)\end{array}$ & $\begin{array}{l}7.90 \\
\text { Prob:(0.0000) }\end{array}$ & $\begin{array}{l}4.441811 \\
\text { Prob:(0.00016) }\end{array}$ & $\begin{array}{l}6.8216 \\
\text { Prob:(0.0000) }\end{array}$ \\
\hline Cross-section Chi-square & $\begin{array}{l}58.66913 \\
\text { Prob:(0.000) }\end{array}$ & $\begin{array}{l}55.1703 \\
\text { Prob: } \\
(0.000)\end{array}$ & $\begin{array}{l}52.1603 \\
\text { Prob:(0.000) }\end{array}$ & $\begin{array}{l}44.704077 \\
\text { Prob: }(0.0005)\end{array}$ & $\begin{array}{l}50.987 \\
\text { Prob:(0.000) }\end{array}$ \\
\hline
\end{tabular}

Table 2. Panel Regression Results

Notes: For the first 4 models, the sample is 1989-2010. For Model 5, the sample covers 1996-2010. All models are estimated under fixed effects assumption. *, **, *** denote significance at 10\%, 5\% and 1\%.t statistics are given in parenthesis.

In Model 1, we added corruption variable is the explanatory variable added to the regression. The sign of the parameter is statistically significant and is positive showing that corruption has a positive impact on economic growth. The results coincide with Tanzi (1998) findings in terms of the positive effects of corruption. Tanzi (1998) notes that the positive effect of corruption on growth is expected to be larger as the size of the underground economy increases, a factor which cannot be quantified appropriately and also cannot be included into the models since no continuous data exists. In Model 2, the democracy variable is added to the regression. While the sign of the parameter estimate is positive, its parameter is statistically significant only at $10 \%$ significance level. An overall assessment of the literature suggests that democracy has a mostly insignificant parameter estimates with either negative and positive signs (see, for example, the reviews of Przeworski and Limongi, 1993; Sirowi and Inkeles, 1990; Przeworski et al., 2000). Adelman and Morris (1967), Bhalla (1994), Chatterji et al.(1993), deLong and Schleifer (1993) and Dick(1974) points at positive; Berg-Schlosser (1984) point at positive or insignificant effects. Though our results suggest statistically significant effects of democracy on growth for Model 2 at $10 \%$ significance level only, a quick investigation of Table 1 shows that, in Model 4, level of democracy has a statistically significant 
effect on growth at $5 \%$ significance level suggesting a positive effect of democratization with a relatively large size of the parameter estimate. Therefore, in addition to the positive sign in Model 2, the statistically significant and the large and positive parameter estimate of democracy suggest that our results are in favor of the literature suggesting positive and significant effects of democratization on economic growth.

In Model 3, the relationship between political instability and economic growth is evaluated. One point to be noted is that, political instability index is an index that ranges between 0 and 100, whereas, as the index becomes closer to 100 , this denotes that political risk is decreasing. Similarly, as the index is close to 0 , political risk decreases. The coefficient of political instability is estimated with a positive sign suggest that as political instability decreases (or as political stability increases), this has a positive effect on economic growth. Further, the highest overall fit is achieved with the 5th model in terms of $\mathrm{R}^{2}$. In Model 5, both corruption and democracy has a positive and statistically significant parameter at 5\% significance level suggesting positive impacts of both corruption and democracy on growth. Further, the third explanatory variable is the political instability, which is estimated with a negative sign in contrast to its positive sign in Model 3. As known in the econometrics, omitted variables could result in biased parameter estimates as occurred in Model 3; therefore, by the inclusion of all explanatory variables representing the corruption, democracy and political instability, we expect that the results obtained in Model 5 could be considered as having more reliability. Therefore, our results in the evaluated models hint correlation between corruption, democracy and political instability though in our checks, the correlation between the variables are less than 0.80 in absolute terms suggesting no perfect multicollinearity. As a result, the results obtained in Model 5 are also in line with the suggestions of Tanzi (1998) and the literature on the democracy and growth relationship discussed above. Further, among the contrasting results in Models 3 and 5 in terms of political instability, if Model 5 is taken into the considerations, similar to corruption, the results are in favor of suggesting that increased political instability contributed in the economic growth. This result is also expected if considered in line with the Tanzi (1998) results since the periods in the economies with increased corruption that is taken as a proxy of the underground economy also coincide with the periods with increased political instability. However, our results should be read with caution: these models do not take the long run relationships between the analyzed variables. Therefore, though our econometric results suggest that in the short run, the political instability had a negative association with economic growth, in the long run, political stability instead of instability could result in increased economic growth. Availability of data also is in favor of this suggestion and we fail to consider testing the long run relations. This approach is left for the researches in the future.

Our overall results suggest that the role of democratization has significant impact on growth for the period of transition whereas, the impact of corruption has also been positive for the countries analyzed. In this regard, the results point that high levels of corruption reached in these countries have significant effects on the informal economy which also translates itself through certain channels that also affect economic growth. However, the evaluation of these channels is also left for future studies.

\section{Conclusion}

If evaluated in terms of economic success, the Middle-European countries are comparatively more successful in terms of economic growth. In the success of these countries, in addition to measures taken in terms of economic reforms, the cooperation of the societies with these reforms in these countries, political stability, socialdemocratization of communist parties and failure to claim the conducted reforms properly, and religious factors have significant roles. As stated by Erickson (1999), among the majority of former USSR member countries, the failure to achieve full transformation of the leadership and parliamentary system in the post-Soviet nations could be named as "bureaucratic capitalism" which could have resulted from certain factors. These factors are listed as inappropriate conduct of the laws, governmental looting activities, existence of mafia and informal economy and failure to receive the social support from the nations' citizens. Nevertheless, these factors encumber the achievement of success and political instability played a significant role in the lack of progress in terms development.

As discussed by Eren and Bildirici (2000), to achieve enhanced economic development levels, the transition countries should pay importance to macroeconomic stability, the establishment of competitive markets, the commitment towards "real" privatization, the ability to achieve improved property rights, the establishment of political stability. However, these goals also require a certain amount of capital stock which are accessed more successfully by the countries located closer to Europe. Compared to literature which suggests that democracy had a mostly insignificant parameter estimates with either negative and positive signs, our results showed a positive and significant effect of democratization on economic growth in the analyzed transition economies.

Similar to the findings in the literature, the parameter of corruption is statistically significant and had positive signs suggesting that corruption had a positive impact on economic growth which could result from the positive effects of the underground economy as stated by Tanzi (1998).

Further, the parameter of political stability is estimated with a positive and with a negative sign showing inconsistent results in two different models. Following this result, though the political instability seemed to 
contribute to economic growth, this result associated with the finding that increased corruption also coincide with increased political instability periods and we noted that these results lack the empirical analyses conducted to evaluate the long run relationships among the evaluated variables. As a policy perspective, among the institutional and socioeconomic factors, further achievements in terms of improving political stability and democratization is expected to have positive effects on the economic growth of the evaluated transition economies in the long run

\section{References}

- Adelman and Morris. 1967. Society, Politics and Economic Development: A Quantitative Approach. Johns Hopkins University Press, Baltimore.

- Alesina and Drazen, 1991. "Why are stabilizations delayed?” American Economic Review, 81, p. 1170.

- Atkins, 1999. “Tajikistan: A Case Study for Conflict Potential”, The Soviet and Post-Soviet Review, 24, p.175.

- Barro, 1994. "Democracy \& Growth”, NBER Working Papers, 4909, National Bureau of Economic Research.

- Barro, 1998. Determinants of Economic Growth: A Cross-Country Empirical Study. 1st Ed. MIT Press, Michigan.

- Berg, Borensztein, Sahay and Zettelmeyer, 1999. "The Evolution of Output in Transition Economies: Explaining the Differences", IMF Working Paper WP/99/73.

- Berg-Schlosser, 1984. “African Political Systems: Typology and Performance",Comparative Political Studies, 17 (4), p. 121.

- Bhalla, 1994. "Freedom and Economic Growth: A Virtuous Cycle?” In Democracy's Victory and Crisis, ed. Axel Hadenius, Cambridge University Press: Cambridge, p. 195.

- Chatterji, Gilmore, Strunk and Vanasin, 1993. "Political Economy, Growth and Convergence in LessDeveloped Countries", World Development, 21, p.2029.

- Choi, 2001. "Unit root tests for panel data", Journal of International Money and Finance, 20, p.249.

- Cornell, 2000. “Uzbekistan: A Regional Player in Eurasian Geopolitics?”, European Security, 9 (2).

- Cornell and Sultan, 2000. "The Asian Connection: The New Geopolitics of Central Eurasia”, Caspian Brief, Marco Polo Magazine 6.

- DeLong, Bradford and Shleifer, 1993. "Princes and Merchants: European City Growth Before the Industrial Revolution", Journal of Law and Economics, 36, p. 671.

- Dick, 1974. “Authoritarian versus Nonauthoritarian Approaches to Economic Development", Journal of Political Economy, 82, p. 817.

- Eren and Bildirici, 2000. "Post Sosyalist Ülkelerde Geçiş Sorunları: Başarı ve Başarısızlıklar”, In Proceedings of METU International Conference in Economics, September 13-16.

- Ericson, 2000. “The Post-Soviet Russian Economic System: An Industrial Feudalism?” Bank of Finland Institute for Economies in Transition (BOFIT) Working Paper, ISSN 1456-811X, p. 1.

- Fidrmuc, 2000. "Political Support for Reforms: Economics of Voting in Transition Countries", European Economic Review, 44, p. 1491.

- Fidrmuc, 2000. "Economics of Voting in Post-Communist Countries", Electoral Studies, 19(2/3), p. 199.

- Fidrmuc, 2003. “Economic Reform, Democracy and Growth During Post-Communist Transition”, European Journal of Political Economy, 19(3), p.583.

- Fischer, 1993. "The Role of Macroeconomic Factors in Growth”, NBER Working Papers, No. 4565.

- Havrylyshyn, Izvorski and van Rooden, 1998. "Recovery and Growth in Transition Economies 1990-97: Stylized Regression Analysis," IMF Working Paper, 98/141.

- Heybey and Murrell, 1999. "The Relationship between Economic Growth and the Speed of Liberalization during Transition", Journal of Policy Reform, 3(2), p. 121.

- IMF, 2017. International financial statistics (IFS) database, http://www.imf.org/en/Data

- Im, Pesaran and Shin. 2003. "Testing for Unit Roots in heterogeneous Panels”, Journal of Economics 115, p. 53.

- Johnson, Kaufmann, and Zoido-Lobaton, 1998. "Regulatory discretion and the unofficial economy", The American Economic Review 88(2), p. 387.

- Krueger, Gary, and Marek Ciolko, 1998. "A Note on Initial Conditions and Liberalization during Transition" Journal of Comparative Economics, 26, p. 718.

- Lee and Lee, 2009. "Energy prices, multiple structural breaks, and efficient market hypothesis", Applied Energy, 86, p. 466.

- Levin, Lin, Chu. 2002. "Unit root tests in panel data: Asymptotic and finite-sample properties", Journal of Econometrics, 108, p. 1.

- $\quad$ Liu, Wu, Zidek, 1997. “On segmented multivariate regressions”, Statistica Sinica, 7, p. 497. 
- Mankiw, Romer, and Weil, 1992. “A contribution to the empirics of economic growth”, The Quarterly Journal of Economics, 107(2), p. 407.

- Milanovic, 1998. "Income, Ineguality and Poverty during the Transition from Planned to Market Economy", World Bank regional and sectoral studies, 1, p. 1-251.

- North, 1990. “A transactions cost theory of government”, Journal of Theoretical Politics 2, p. 355.

- Olson, 1993. "Dictatorship, democracy, and development", American Political Science Review, 87,p.567.

- Olson, 2000. Power and prosperity: Outgrowing communist and capitalist dictatorships. Basic Books, New York.

- Przeworski and Limongi, 1993. "Political Regimes and Economic Growth", The Journal of Economic Perspectives, 7, p. 51.

- Rodrik, 2000. "Institutions for High-Quality Growth: What They Are and How to Acquire Them", CEPR Discussion Paper No. 2370.

- Roland, 2000. Transition and economics: Politics, markets, and firms. MIT Press, Cambridge.

- Sirowy and Inkeles, 1990. "The Effects of Democracy on Economic Growth and Inequality: A Review." Studies in Comparative International Development, 25, p. 126.

- Tanzi, 1998. "Corruption around the world Causes, consequences, scope, and cures", International Monetary Fund WP 98/63.

- World Bank, 2017. World Development Indicators, WDI, http://data.worldbank.org/data-catalog/worlddevelopment-indicators 